\title{
Trends in counts of manatees Trichechus manatus latirostris from 1987 to 2006 in waters of Sarasota County, Florida, USA
}

\author{
Kerri M. Scolardi ${ }^{1,4}$, Lori H. Schwacke ${ }^{2}$, Jessica K. Koelsch ${ }^{3}$, John E. Reynolds III ${ }^{1, *}$, \\ Teresa J. Kessenich ${ }^{1,5}$, Jay M. Sprinkel ${ }^{1}$, Janet G. Gannon ${ }^{1,6}$ \\ ${ }^{1}$ Mote Marine Laboratory, 1600 Ken Thompson Parkway, Sarasota, Florida 34236, USA \\ ${ }^{2}$ National Oceanographic and Atmospheric Administration, 219 Fort Johnson Rd., Charleston, South Carolina 29412, USA \\ ${ }^{3}$ The Ocean Conservancy, 449 Central Ave, Suite 200, St. Petersburg, Florida 33701, USA \\ ${ }^{4}$ Present address: 514 N Weber St., Colorado Springs, Colorado 80903, USA \\ ${ }^{5}$ Present address: Southwest Florida Water Management District, Sarasota Service Office, 6750 Fruitville Road, Sarasota, \\ Florida 34240-9711, USA \\ ${ }^{6}$ Present address: Bowdoin College, Biology Department, Bowdoin College, 6500 College Station, Brunswick, \\ Maine 04011, USA
}

\begin{abstract}
To demonstrate the utility of distributional surveys for assessing relative abundance and trends in counts for a discrete area of coastline, aerial survey data from Sarasota County, Florida, USA, were analyzed for the years 1987 to 2006. The study area was divided into 3 regions: the Sarasota Bay Region (SBR; $N=353$ surveys), Lemon Bay $(\mathrm{N}=368)$, and the Myakka River $(\mathrm{N}=209)$. Manatee counts varied significantly across seasons $(p<0.0001)$ for all 3 regions. Manatees within Sarasota County utilized open bays primarily in the warmer months. Such usage may have been influenced by resource availability. Conversely, usage of the Myakka River peaked in winter months when manatees seek warm-water refugia such as Warm Mineral Spring. Marginal means for yearly counts within Lemon Bay and the SBR increased significantly, beginning midway through the survey period (1996) until the early 2000s. In contrast, mean yearly counts within the Myakka River decreased over this time period. After record lows in 2003 for Lemon Bay and the Myakka River, and a considerable decline in 2004 for the SBR, mean yearly counts for all 3 regions showed an increasing trend over the remaining 2 yr of the study. Greater protection of manatee habitat and availability of forage coincided with the increase in numbers of manatees using Sarasota County waters during the 1990s, and the subsequent decline in numbers may be indicative of the increase in mortality in recent years due to watercraft collisions and severe red tide events.
\end{abstract}

KEY WORDS: Florida manatee · Trichechus manatus latirostris · Aerial survey · Seasonal distribution · Abundance $\cdot$ Sarasota County $\cdot$ Manatee refuge $\cdot$ Conservation

Resale or republication not permitted without written consent of the publisher

\section{INTRODUCTION}

Florida leads the USA in terms of coastal population growth, with a $75 \%$ percent increase in residents of coastal counties over the last 2 decades (Crossett et al. 2004). The intensive coastal development for agricultural, residential, and commercial purposes has consequentially led to the destruction or degradation of aquatic habitat in regions that have historically served as foraging, nursing, and resting areas for the endangered Florida manatee Trichechus manatus latirostris. The loss of valuable habitat and increasing mortality from both human-related activities and natural causes threaten the recovery of the species (Reynolds 1999, USFWS 2001). Unfortunately, insufficient data regarding regional trends in abundance of manatees and the effectiveness of ongoing regulatory measures have made it difficult to promote effective conservation of Florida manatees (Marine Mammal Commission 2005). 
Nowhere is this problem more evident than in southwestern Florida, the region of the state that has experienced the fastest growth in human population every decade since 1960 (Smith 2005). Manatees in southwestern Florida experience a high incidence of mortality due to both natural causes (i.e. red tides, cold stress, and disease) and anthropogenic (mostly watercraft-related) activities (Ackerman et al. 1995, Langtimm et al. 2004). As a result, the southwestern region is the area of the state where it is most likely that the resident subpopulation of manatees may be decreasing (Runge et al. 2004).

A significant proportion of manatees in southwestern Florida utilize Sarasota County during non-winter months. The county contains $135 \mathrm{~km}^{2}$ of water area (Tomasko et al. 1996), much of it shallow bays and estuaries that offer favorable resources to manatees. Nabor \& Patton (1989) did, in fact, conclude from $4 \mathrm{yr}$ of aerial survey data that the rivers and inland bays of Sarasota County provide important feeding and resting areas for manatees during summer, and serve as a travel corridor for manatees migrating to and from winter refuge sites during fall and spring.

Aerial surveys have been used for decades as a tool to answer specific questions with regard to marine mammal population size and trend, habitat use, and species diversity. For sirenian populations worldwide, aerial surveys have been used extensively since the 1970s. Three types of aerial survey, distributional, intensive search, and transect, are routinely performed when studying sirenians (J. E. Reynolds et al. unpubl. data). Distributional surveys (e.g. Colmenero \& ZarateBecerra 1990, Mou Sue et al. 1990, Morales-Vela et al. 2000, 2003, Wright et al. 2002) provide useful information on local distribution and habitat use, but they do not generally answer questions regarding regional population size and trends (Ackerman 1995, Lefebvre et al. 1995). Intensive search surveys (e.g. Packard 1985, Garrott et al. 1994, Reynolds \& Wilcox 1994, Craig et al. 1997, Craig \& Reynolds 2004, Edwards et al. 2007) attempt to generate indices of abundance or trends at specific locations of interest (e.g. warm-water refugia for Florida manatees in winter) for conservation and management; however, they do not assess regional distribution or large-scale habitat use. Transect surveys (see Burnham et al. 1980) represent the best aerial survey method by which to generate estimates of population size and trends, as they produce statistically robust models that can correct for biases (e.g. Cook \& Jacobson 1979, Pollock \& Kendall 1987, Conroy et al. 1988, Marsh \& Sinclair 1989). These types of surveys have been used most effectively for dugongs in Australia (e.g. Marsh \& Sinclair 1989, Marsh et al. 2004, Pollock et al. 2006), although they have been used for manatee studies as well (e.g. Morales-Vela \& Olivera-Gómez 1994, Miller et al.
1998). Transect surveys also have an advantage over other survey methods in that they are less costly and less time-consuming (Burnham et al. 1980), but the reduction in coverage means they may miss local 'hotspots'. Thus, each survey type provides a means by which to address some, but not all, questions of importance when assessing sirenian populations.

The surveys reported in this study represent distributional surveys. They were designed to answer questions of importance to a particular Florida county (Sarasota County) as it considered optimal ways by which to balance human development and activities with manatee habitat use and conservation. Habitat use questions have been addressed by Gannon et al. (2007); the present paper attempts to demonstrate the utility of these surveys to assess relative abundance and trends in counts for a discrete area of coastline.

Temporal and spatial trends in relative manatee abundance and distribution, based on observations from long-term, year-round aerial survey studies, were reported by Powell \& Rathbun (1984) for northwestern Florida, by Provancha \& Provancha (1988) for the eastcentral coast, and by Wright et al. (2002) for the central Gulf coast of Florida. These types of data have not previously been available for southwestern Florida. The present paper describes annual and seasonal trends in counts of manatees in Sarasota County between 1987 and 2006.

\section{MATERIALS AND METHODS}

Surveys. The inshore and near-shore waters of Sarasota County, including Gulf of Mexico beaches, open bays, estuaries, rivers, canals, boat basins, and deepwater navigation channels, were surveyed for manatees from 1987 to 2006 . The study area was divided into 12 zones based on geographic characteristics or defined landmarks (Fig. 1). Survey coverage of the study area varied somewhat within and among years during the study; therefore, zones that were not surveyed consistently and/or located outside of the county (Zones 1, 2, 9 to 11 ) were excluded from the analyses presented here.

Zones that were consistently covered are grouped into 3 sub-areas, or regions, from north to south: (1) Sarasota Bay Region (SBR; Zones 3 through 7), (2) Lemon Bay (Zone 8), and (3) the Myakka River (Zone 12) (Fig. 1). The SBR extends from northern Sarasota Bay to the southern end of a narrow, deep-water channel known locally as the Venice Bypass canal, and includes numerous enclosed bays, creeks, dredged canals, and boat basins, as well as 3 inlets that provide access to the Gulf of Mexico. The Lemon Bay region, or Zone 8, starts south of the Venice Bypass canal and ends mid-bay. This Zone has no inlets and fewer 


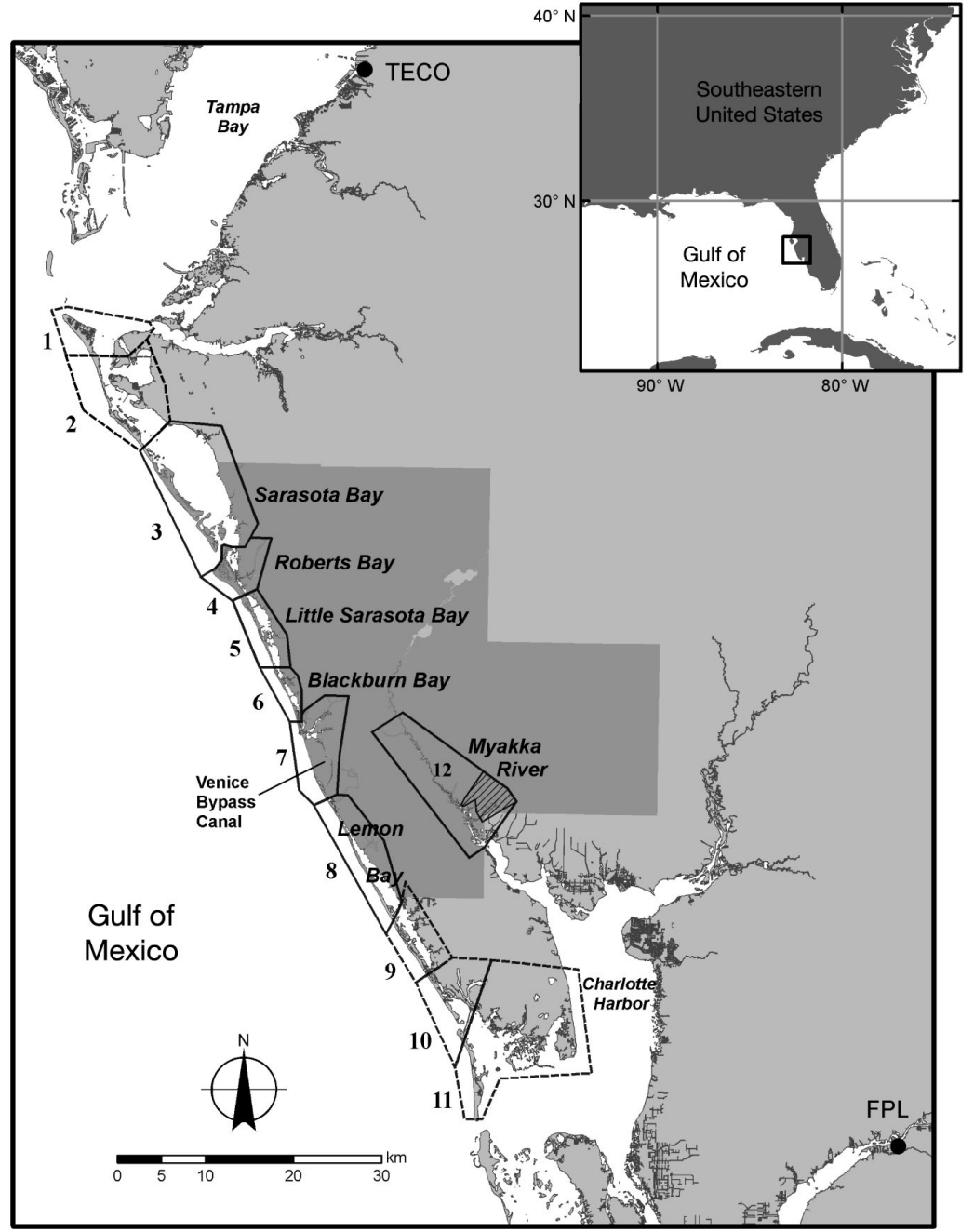

Fig. 1. Study area showing zones consistently surveyed over the period from 1987 to 2006 (solid line polygons) and zones excluded from the analysis due to incomplete coverage and/or location (dashed line polygons). The hatched area within Zone 12 shows the portion of the Myakka River not surveyed before 1996. Dark gray shaded region of land represents Sarasota County. TECO: Tampa Electric Company's Big Bend power plant; FPL: Florida Power \& Light Company's Fort Myers power plant

anthropogenic attributes, with the exception of a small tributary, Forked Creek, that has extensive shoreline armoring and numerous boat docks. Zone 12 encompasses a section of the downstream portion of the Myakka River, which is tidal and brackish, and has a mix of canals, boat basins, and natural shoreline vegetation. This region also includes Salt Creek, a spring run associated with Warm Mineral Spring, a warmwater refuge. For the Myakka River, only data from 1996 to 2006 were included in the analysis. Years prior to 1996 were omitted due to the exclusion of Salt Creek from the survey during this time.

Flights were conducted in a single-engine, highwinged Cessna 172 aircraft at an altitude between 155 and $250 \mathrm{~m}$ and an air speed of 150 to $160 \mathrm{~km} \mathrm{~h}^{-1}$. An ex- perienced observer occupied the right front seat. The observer wore polarized sunglasses and observed with the window open to reduce glare and increase visibility. Employing the 'extendedarea' survey technique (Packard 1985), the aircraft followed a pre-determined route designed to cover areas in which manatees Trichechus manatus latirostris were most likely to be observed, i.e. areas accessible to the species. When manatees or signs of their possible presence (e.g. mud plumes, disturbed water surface) were observed, the plane slowed and circled until all individuals were counted or repetitive counts became consistent (Ackerman 1995, Lefebvre et al. 1995). The location, number of adults, number of calves, and direction of travel were recorded on standardized map sets during the flight. These data were later transposed into a Geographic Information System (GIS) database. Surveys were delayed or aborted if winds exceeded $30 \mathrm{~km} \mathrm{~h}^{-1}$ or water surface conditions were greater than 3 on the Beaufort scale (scattered white caps; Ackerman 1995).

From 1987 to 2004 the study area was typically surveyed twice per month, although some months had only a single survey or were missed completely due to inclement weather (Table 1). Coverage of the Myakka River region before 1996 was inconsistent; therefore data from these years were omitted from the analyses for this study. The total numbers of surveys included in the study for each region are: SBR: $\mathrm{N}=355$; Lemon Bay: $\mathrm{N}=366$; Myakka River: $\mathrm{N}=209$.

Data treatment and statistical analysis. To assess trends in manatee abundance, the total count of manatees was used as an index of abundance, assuming some unknown functional relationship between count and actual abundance (Caughley 1977). Consistency in survey protocols and coverage of the 'core' regions support the assumption that counts should be comparable over time. Count data often follow a Poisson distribution, with a variance that is proportional to the mean. Therefore, a generalized linear model (GLM) using a Poisson distribution with a log-link function (McCullagh \& Nelder 1989) was used to examine seasonal and annual variation in mean counts. Seasons were defined as winter (December to February), spring (March to May), summer (June to August), and fall 
Table 1. Number of surveys flown by season for the 3 regions, Sarasota Bay Region (SBR), Lemon Bay (LB), and Myakka River (MR), from 1987 to 2006. (-) No data available

\begin{tabular}{|c|c|c|c|c|c|c|c|c|c|c|c|c|}
\hline \multirow{2}{*}{ Year } & \multicolumn{3}{|c|}{ Winter } & \multicolumn{3}{|c|}{ Spring -} & \multicolumn{3}{|c|}{ Summer } & \multirow[b]{2}{*}{ SBR } & \multirow{2}{*}{$\begin{array}{c}\text { Fall } \\
\text { LB }\end{array}$} & \multirow[b]{2}{*}{ MR } \\
\hline & SBR & LB & MR & SBR & LB & MR & SBR & LB & MR & & & \\
\hline 1987 & 5 & 3 & - & 5 & 6 & _- & 5 & 6 & - & 4 & 4 & - \\
\hline 1988 & 3 & 3 & - & 4 & 4 & - & 7 & 7 & - & 5 & 5 & - \\
\hline 1989 & 4 & 4 & - & 5 & 6 & - & 3 & 3 & - & 4 & 4 & - \\
\hline 1990 & 1 & 1 & - & 4 & 3 & - & 3 & 3 & - & 3 & 3 & - \\
\hline 1991 & 2 & 2 & - & 0 & 0 & - & 2 & 4 & - & 1 & 2 & - \\
\hline 1992 & 2 & 2 & - & 3 & 3 & - & 3 & 3 & - & 3 & 3 & - \\
\hline 1993 & 4 & 4 & - & 7 & 7 & - & 6 & 6 & - & 6 & 6 & - \\
\hline 1994 & 6 & 6 & - & 6 & 6 & - & 6 & 6 & - & 6 & 6 & - \\
\hline 1995 & 6 & 6 & - & 6 & 6 & - & 6 & 6 & - & 6 & 6 & - \\
\hline 1996 & 5 & 5 & 5 & 7 & 8 & 7 & 6 & 6 & 6 & 5 & 6 & 6 \\
\hline 1997 & 5 & 6 & 6 & 6 & 6 & 6 & 6 & 6 & 6 & 6 & 6 & 6 \\
\hline 1998 & 5 & 6 & 6 & 4 & 6 & 6 & 6 & 6 & 6 & 6 & 6 & 6 \\
\hline 1999 & 6 & 6 & 6 & 5 & 6 & 6 & 6 & 6 & 6 & 5 & 5 & 5 \\
\hline 2000 & 7 & 7 & 7 & 6 & 6 & 6 & 6 & 6 & 6 & 6 & 6 & 6 \\
\hline 2001 & 3 & 3 & 3 & 5 & 5 & 5 & 6 & 6 & 6 & 3 & 3 & 3 \\
\hline 2002 & 0 & 0 & 0 & 0 & 0 & 0 & 6 & 6 & 6 & 3 & 3 & 3 \\
\hline 2003 & 1 & 1 & 1 & 4 & 4 & 4 & 5 & 5 & 5 & 4 & 4 & 4 \\
\hline 2004 & 5 & 5 & 5 & 5 & 6 & 6 & 6 & 6 & 5 & 4 & 4 & 4 \\
\hline 2005 & 3 & 3 & 3 & 5 & 5 & 5 & 5 & 5 & 5 & 5 & 5 & 5 \\
\hline 2006 & 3 & 3 & 3 & 3 & 3 & 3 & 3 & 3 & 3 & 2 & 2 & 2 \\
\hline
\end{tabular}

(September to November). Year was treated as a categorical factor rather than a continuous covariate to avoid making the assumption of a linear trend. The median numbers of complete surveys per season per year were 5.0 and 6.0 for the SBR and Lemon Bay, respectively (excluding the years 1991 and 2002). To preserve the ability to test for interaction effects between year and season and to facilitate straightforward interpretation we omitted the years 1991 and 2002 from the GLM analysis. However, data from these years are still graphically represented for the seasons in which surveys were conducted. A similar analysis was conducted for the Myakka River, but including only the years from 1996 to 2004. Residual plots, as well as deviance and Pearson Chi-squared statistics, were examined to confirm an adequate model fit. When season was determined to be a significant factor affecting manatee counts, the analysis was followed by pairwise comparisons between each of the 4 seasons. Critical values for the pairwise comparisons between seasons were adjusted using a Bonferroni approach, and the threshold value was set to $0.05 / 6=0.008$.

\section{RESULTS}

\section{Sarasota Bay Region}

Within the SBR, mean counts of manatees Trichechus manatus latirostris varied significantly among seasons $(p<0.0001)$ and years $(p<0.0001)$.
Pairwise comparisons showed that counts differed between all seasons (summer vs. fall, $\mathrm{p}=0.0063$; for all other comparisons $\mathrm{p}<0.0001$ ). The lowest counts in the SBR were from the winter season and were at least 4fold lower than counts made in the warmer seasons (Fig. 2). The marginal mean for yearly manatee counts increased over most of the survey period, with a significant increase occurring between 1996 and 1997. Mean counts peaked in 2001 and then sharply declined after 2003. From 2004 to 2006, mean counts for manatees remained low relative to counts from the previous $7 \mathrm{yr}_{\text {; }}$ however, mean counts from these years were still nearly 2 -fold greater than those from the first 10 yr (Fig. 3).

The difference in counts between years was notable for spring, summer, and fall seasons, but not for the winter season (Fig. 3). This was supported by a significant interaction effect between season and year $(p=0.0006)$. At its peak $(2001)$, the mean summer count (and 95\% confidence intervals, CI) for the SBR $(\bar{x}=47.2,95 \% \mathrm{CI}=37.6$ to 56.7$)$ was more than double the mean count from the 1987 to 1996 survey period $(\bar{x}=22.3,95 \% \mathrm{CI}=18.8$ to 25.8$)$.

\section{Lemon Bay}

Mean counts of manatees within Lemon Bay also varied significantly among seasons $(p<0.0001)$ and years $(p<0.0001)$. Despite the narrow range in counts across seasons, fall counts were determined to 

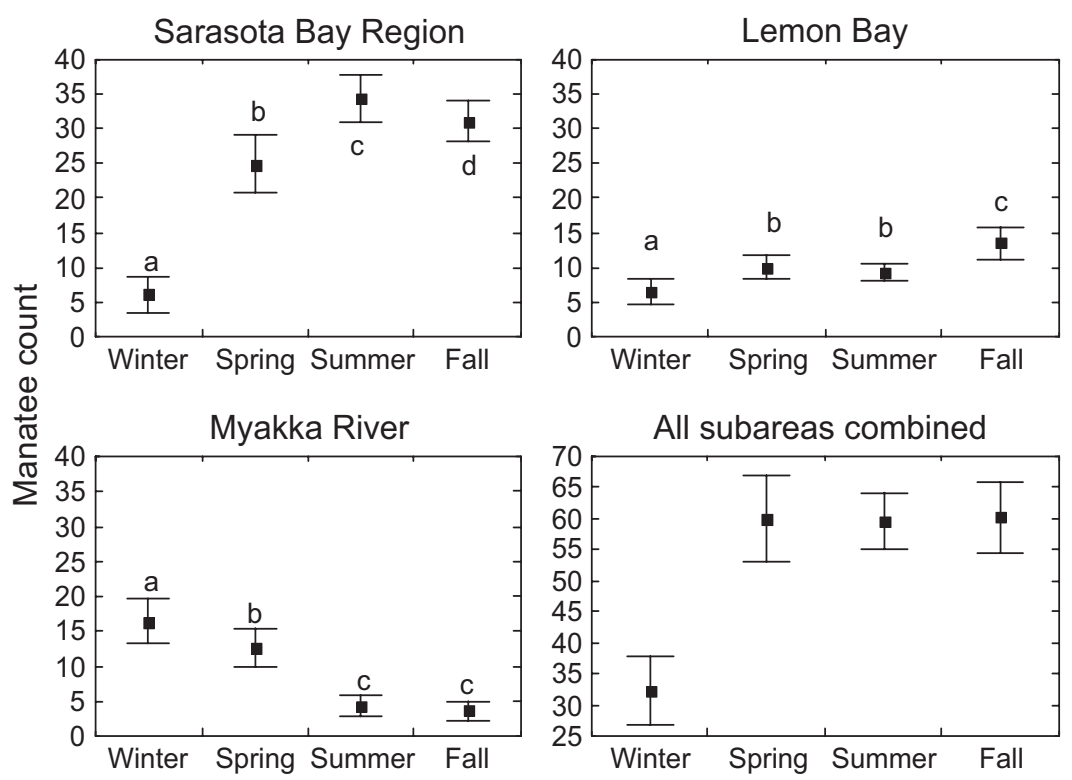

Fig. 2. Trichechus manatus latirostris. Mean and 95\% confidence interval for manatee counts across seasons. Letters indicate homogeneous groups, adjusted $\alpha=0.008$

be significantly higher than those for other seasons, and winter counts were significantly lower (Fig. 2). Spring and summer counts did not differ significantly from one another $(p=0.3327)$. Marginal means for yearly counts showed little change during the first half of the survey period, increased sharply from 1996 to 1999, and subsequently declined over the next few years (Fig. 3). By 2003, the mean count was as low as, or even lower than, the counts observed during the first half of the survey period. Mean counts within Lemon Bay rebounded after 2003, although the large confidence intervals for the mean count in 2006 rule out any certainty of an increasing trend.

The trends in counts within Lemon Bay were fairly consistent across seasons, with the exception of a few years (Fig. 3), leading to a significant interaction effect between year and season ( $p<0.001)$. In 2006, the mean fall count was unusually high (over double the previous year), but the mean summer count was one of the lowest.

\section{Myakka River}

Mean counts of manatees within the Myakka River varied significantly among seasons $(\mathrm{p}<0.0001)$ and years $(p<0.0001)$. The highest counts were seen in winter, followed by spring (Fig. 2). There was no significant difference between summer and fall counts ( $p=0.5222 ;$ Fig. 2). Mean yearly manatee counts slowly decreased from 1996 to their lowest point in 2003 (Fig. 3). This low was followed by an increasing trend in mean counts, which was largely driven by winter and spring counts (Fig. 3).

Similar to the SBR, there was a significant interaction effect between season and year for counts within the Myakka River $(\mathrm{p}<0.0001)$. Winter and spring counts showed the greatest variation among years, although the trends for these seasons rarely coincided with each other (Fig. 3).

\section{DISCUSSION}

\section{Seasonal and annual differences in manatee counts}

Aerial survey data showed that manatees Trichechus manatus latirostris use Sarasota County waters yearround; however, different regions assume differential importance seasonally. The seasonal differences observed within all 3 regions were due primarily to movements of manatees associated with cold winter weather. During winter, manatee distribution in most parts of Florida is governed primarily by the animals' need to have access to warm water (Irvine 1983, Kinnaird 1985, Reid et al. 1991, Wright et al. 2002, Deutsch et al. 2003, Craig \& Reynolds 2004). The only warm-water refuge in Sarasota County is located off the Myakka River, at Warm Mineral Spring. The warm $\left(\sim 29^{\circ} \mathrm{C}\right)$ discharge from the spring's headwaters flows roughly 2 miles southwestward to the river through Salt Creek, where manatees aggregate. Preliminary analysis of photoidentification data from 1990 through 2003 indicates that approximately $19 \%$ of identified manatees utilizing the Myakka River and Warm Mineral Spring during winter months were documented in Sarasota County waters during summer months (Florida Fish and Wildlife Conservation Commission unpubl. data). It is likely though, based on telemetry data, that many of the Warm Mineral Spring manatees return to waters south of Sarasota County during warmer months (M. Barlas pers. comm., 15 June 2009), including Charlotte Harbor, the state's second largest open water estuary.

In addition to providing warm-water access, the Myakka River is entirely regulated with motorboat speed zones and offers shallow ( $<1.5 \mathrm{~m}$ deep), sheltered areas and some aquatic and shoreline vegetation. However, the dark, tannin-stained waters of the 


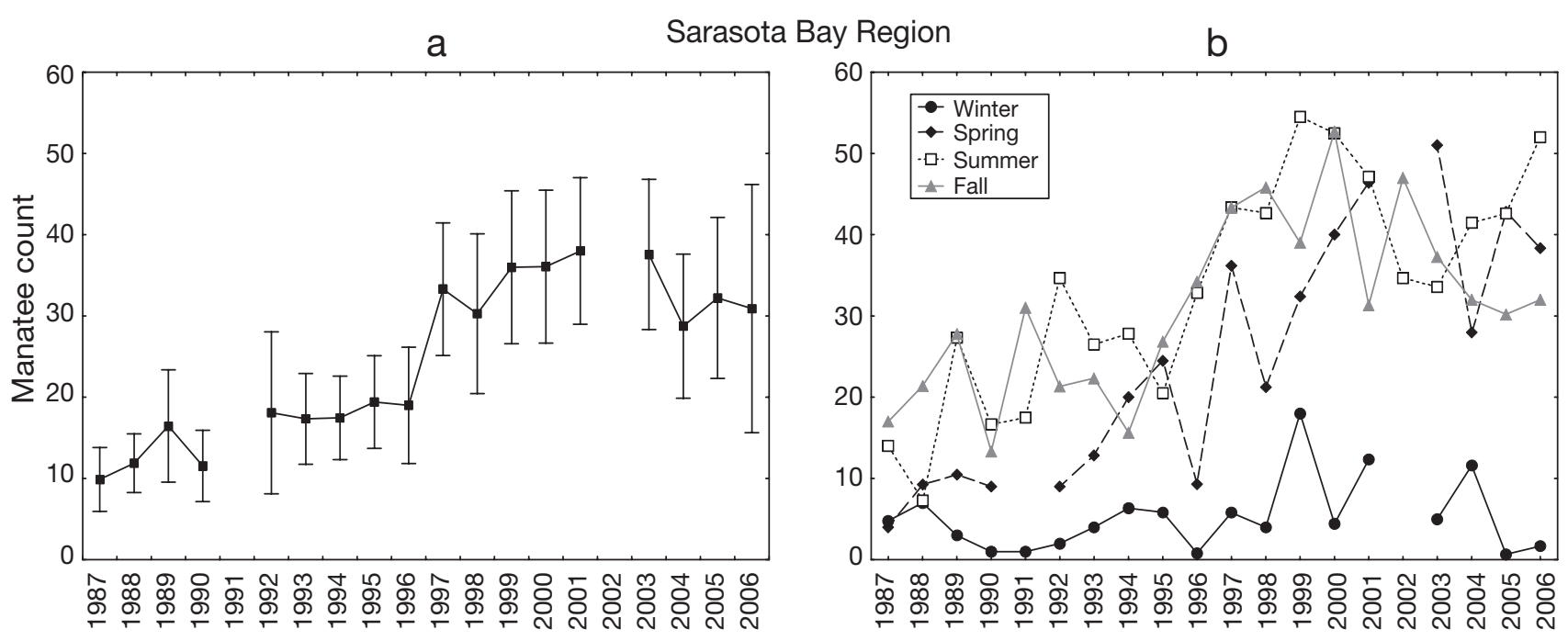

\section{Lemon Bay}
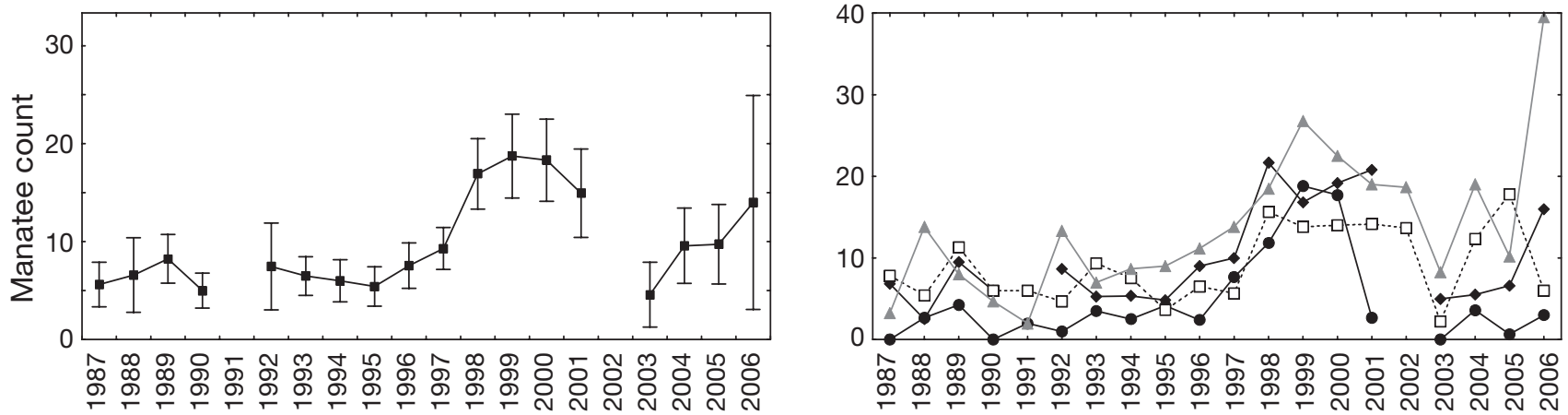

Myakka River
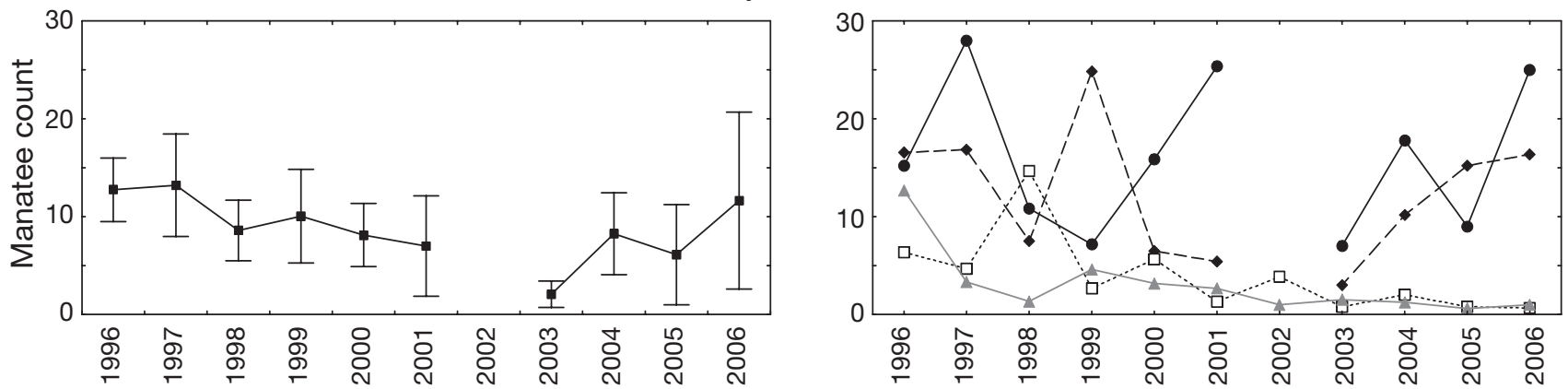

Fig. 3. Trichechus manatus latirostris. Marginal means for: (a) yearly manatee counts with $95 \%$ confidence intervals and (b) counts by season for the Sarasota Bay Region and Lemon Bay over the entire 20 yr survey period and for Myakka River from 1996 to 2006. Data for 1991 and 2002 are not represented due to fewer than 5 surveys being conducted during winter and winter/spring seasons, respectively

river limit growth of submerged aquatic vegetation; hence, the river is a less suitable habitat for manatees outside of the winter months.

During late spring and early summer, manatees disperse from their winter refuge sites and move into locations such as the SBR and Lemon Bay, where adequate forage, fresh water to drink, and quiet locations for females and calves are available (Gannon et al.
2007). The SBR is located between 2 primary winter refuges on the west coast, Tampa Electric Company's (TECO) Big Bend power plant located $60 \mathrm{~km}$ north in Tampa Bay and Florida Power \& Light Company's (FPL) Fort Myers power plant located $100 \mathrm{~km}$ to the south (USFWS 2001, Laist \& Reynolds 2005); consequently, the SBR receives a large influx of manatees during the warm season, as indicated by the high sum- 
mer and fall counts. Telemetry and photo-identification studies have documented the use of Sarasota Bay over consecutive summers by identifiable individual manatees which, in winter, frequented either the Big Bend power plant or the Fort Myers power plant (Koelsch 1997, Gorzelany 2003). In addition, Koelsch (1997) demonstrated natal philopatry among offspring of females that frequented Sarasota Bay. For the southwest population of manatees, the SBR provides critical habitat and is an essential non-winter destination.

Lemon Bay's highest counts occurred during fall. This seasonal increase might be due in part to an increase in the number of manatees using Forked Creek during this time of year. Water temperatures in the upper portion of the creek are slightly elevated compared to bay waters, and small aggregations of manatees can be found here during cooler periods, such as cold snaps (Gorzelany 2003). Also, Lemon Bay is situated between the SBR and the southerly winter refuges, including the Fort Myers power plant and the Myakka River and thus serves as both a warm-season destination and a travel corridor. We speculate that manatees intermittently move in and out of Lemon Bay throughout spring and summer, but, during the fall season, they start to migrate slowly into a location with easy access to warmer water, such as Forked Creek or refuges farther south, while still providing for their nutritional needs. This scenario is similar to the 'stepping stone' seasonal manatee migration described by Reid et al. (1991) that occurs along the Atlantic coast (see also Hartman 1974, Shane 1983, Kinnaird 1985, Provancha \& Provancha 1988) and along the west coast of Florida (Rathbun et al. 1990).

In our interpretation of the seasonal trend data, we make the assumption that seasonal changes in visibility did not influence the results. A number of authors have discussed problems associated with visibility bias in aerial survey counts (Packard et al. 1985, Marsh \& Sinclair 1989, Lefebvre et al. 1995, Craig et al. 1997, Wright et al. 2002), noting that physical conditions such as water clarity, turbidity, surface choppiness, and surface glare all affect visibility (Reynolds \& Wilcox 1994). Survey protocols established at the beginning of the present study ensured surveys were flown under similar physical conditions year-round. However, biological factors that diminish water clarity during the summer months in the SBR and Lemon Bay (water clarity is poor year-round in the Myakka River), such as increased run-off from rain and persistent phytoplankton blooms in the bays, were not accounted for. If these factors did influence seasonal counts, then we would expect counts to be lower during summer than during any other season. This was not the case, however, as counts were highest during summer in the SBR and lowest during winter in both regions. There- fore, we are confident that the results presented here reflect the true seasonal trends in manatee counts.

Aerial survey data from the present study indicate that manatee counts within Sarasota County waters have also varied significantly across years. As with seasonal data, annual counts within the SBR and Lemon Bay are also subject to visibility bias. Changes in water quality have been documented for the SBR, and those changes have affected water clarity over time in this region (Kurz et al. 1999, Dixon \& Perry 2003). Reductions in point source pollution in Sarasota Bay during the 1980s led to increased water clarity beginning in the early 1990s (Johansson \& Greening 1999, Kurz et al. 1999), which coincides with the increase in counts of manatees during this period. In addition, the drop in mean counts within the SBR in 1998 may be attributable to a temporary reduction in water clarity resulting from increased rainfall/stormwater runoff during the 1997/1998 El Niño (Tomasko et al. 2005). However, water clarity has returned to its improved state, but mean manatee counts within the SBR decreased after 2001. Water clarity change does not explain count trends within Lemon Bay either. This relatively non-urbanized area has not been subjected to excessive pollution from waste treatment facilities and storm-water runoff, as was the case in Sarasota Bay during the 1970s and early 1980s, and, consequently, relatively little change in water clarity has occurred (Tomasko et al. 2005). Therefore, while visibility may have influenced counts in the SBR during particular years, it does not alone explain the major trends seen throughout the county.

Manatee counts can also be influenced by aerial survey methodology and observer differences (Lefebvre et al. 1995). Numerous observers participated in this project, which potentially contributed to variation in counts. However, this effect was likely mitigated because 'new' observers were trained by previous observers, used the same survey methodology, and had aerial survey experience prior to becoming a primary observer. It is also worth noting that the period with the most significant change in counts (1996 to 2000) within the SBR and Lemon Bay had the same primary observer as a surveyor. Therefore, we are confident that these observer differences had a minimal effect on the major trends in counts.

We believe the annual trends reported here are indicative of a true change in the use of Sarasota County waters by manatees over time, due either to local immigration to and emigration from the area or to regional changes in the abundance of the population of Florida manatees, or both. In Tampa Bay, higher winter counts were attributed to increased immigration of manatees from surrounding areas, likely due to greater protection at winter aggregation sites (Wright 
et al. 2002). Extensive manatee protection zones were established throughout Sarasota County in 1992, including a year-round 'No Entry' zone known as Pansy Bayou. An increasing number of manatees may have responded to the availability of these protected areas within county waters during the 1990s by immigrating to the SBR and Lemon Bay during the warmer seasons, when water temperature is not the dominant factor influencing their distribution.

In addition to increased protection, the rising numbers of manatees using the SBR and Lemon Bay during the 1990s may have been further bolstered by an increase in the availability of forage. The upward trend in summer/fall manatee counts in the SBR and Lemon Bay during the 1990s and the subsequent decline after 2001 coincides with a documented expansion of seagrass coverage in Sarasota Bay during the 1990s, followed by a slight decrease in seagrass extent between 1999 and 2004 (Dixon \& Perry 2003, Dawes et al. 2004, Tomasko et al. 2005). Although seagrass coverage in Lemon Bay has remained relatively unchanged since 1987 (Tomasko et al. 2005), long-term changes in habitat within the SBR may have an impact on the use of Lemon Bay by manatees due to the proximity and size of Sarasota Bay. The influence of changes in seagrass extent on the trends reported here should, however, not be overstated, as not much is known about changes in seagrass composition in these regions, and some studies have shown that manatees select certain feeding areas with preferred species of aquatic vegetation (Hartman 1971, Ledder 1986, Provancha \& Hall 1991, Koelsch 1997).

While Myakka River counts would not be affected directly by the extent of seagrass, a lack of adequate foraging areas nearby would certainly make this area less desirable as a refuge. Nonetheless, the Myakka River is largely a cold-season destination, when manatee distribution is heavily governed by thermal needs. Therefore, the decreasing trend in mean counts across years, influenced largely by the variability in winter and spring counts, is more likely related to the annual variations in water temperatures than any of the factors mentioned above. Unfortunately, water temperature data from the Myakka River for this period were not available, and we were subsequently unable to test this hypothesis.

Changes in resource availability and protection may have influenced yearly manatee counts; yet, due to the fact that manatee trend data comparable to those reported here for Sarasota County are not available for neighboring counties, we are unable to determine with certainty whether migration actually occurred. Statewide synoptic surveys have shown that the regional population of Florida manatees has changed over time, although there are a number of uncertainties involved in the determination of these abundance estimates (O'Shea \& Ackerman 1995, FFWCC 2002, Wright et al. 2002). Nonetheless, evidence that the Florida manatee population along the west coast increased between the 1970s and mid-1990s (Ackerman 1995, Wright et al. 2002) coincides well with the increasing counts within the SBR and Lemon Bay during the early part of the survey period. The decrease in counts that occurred later in the survey period for these regions may indicate a decline in the regional population of manatees. This decline appears to be supported by low adult survival estimates reported by Langtimm et al. (2004) and a potentially negative population growth rate for the southwestern population reported by Runge et al. (2004), although both studies acknowledge uncertainties in these estimates due to inadequate coverage of the southwest region. What is certain is that state-wide manatee mortality has continually risen since the 1980 s, with the largest percentage attributed to watercraft-related mortality (average 25\%; FWRI 2007). A number of red tide events in recent years (1996, 2003, and 2005) also significantly increased mortality in those years. The combined threats from both watercraft injuries and red tides have undoubtedly made this subpopulation particularly vulnerable. Higher counts from the most recent years of the study may be promising news for managers; however, considering the high variance in our counts for 2006, it is premature to confirm an increasing trend in the abundance of manatees.

\section{Appropriate spatial scale; lessons learned}

The aerial survey results reported here involve longterm efforts to assess the distribution, habitat use, and trends in counts of manatees occupying the waters of a single county (Sarasota) in the State of Florida. The primary goal of conducting the surveys was to provide the managers of that county with up-to-date information that would inform decisions with regard to waterways management, coastal development, and other phenomena that could affect manatee presence, distribution, and abundance.

What can be learned and applied more generally from the present study? First, it is important to recognize that the surveys achieved their primary goal. The data have been extremely useful to county managers in developing a well-informed and effective Manatee Protection Plan, as mandated by state statute (Gorzelany 2003). The presence of such an extensive, year-round database allowed Sarasota County to be among the leaders in planning human activities in a way that should minimize effects on manatees and their habitat. 
However, the spatial scale of the surveys limits what can be understood with regard to manatee status and trends in southwestern Florida as a region. For example, changes in counts in Sarasota County can reflect regional changes in habitat use and distribution, but do not necessarily indicate regional changes in manatee abundance. Without doing aerial surveys on a regional basis, it will be difficult to draw conclusions about the status of the southwestern management unit.

Thus, our spatially focused long-term surveys have great utility to inform management actions at a local level, but are less useful in addressing issues or questions regionally. Nonetheless, without a commitment for long-term funding from the State of Florida or adjoining counties, the Sarasota County manatee surveys represent a unique dataset for manatees in Florida, and the trends in counts, imperfect as they may be for assessments of manatee trends in abundance in southwestern Florida, can provide an early warning system with regard to the region-wide status of manatees.

As aerial surveys become more expensive due to fuel costs and as agencies and other organizations see budgets becoming leaner, the challenge for scientists studying manatees in Florida will be to use long-term funds to simultaneously (1) answer specific, critical conservation questions as clearly as possible and (2) shed insight on as many other questions and issues as possible.

Acknowledgements. We thank the many dedicated pilots and observers who have been involved in this study over the last $18 \mathrm{yr}$, including B. Freeman, L. Lawrence, P. Graybill, S. Sorenson, G. Baker, J. Gorzelany, R. Nostrom, A. Dukeman, P. Nabor, C. Englund, and E. Quintana. We especially acknowledge G. Patton, who began the aerial survey program at Mote Marine Laboratory. The surveys could not have been accomplished without the cooperation and patience of the air traffic controllers from the Sarasota-Bradenton Airport and the Tampa International Airport, to whom we are extremely grateful. Thanks also go to D. Gannon and E. Quintana for their helpful comments on earlier drafts of this manuscript, and to D. Semeyn for her assistance with the final revisions. Funding was primarily provided by the Sarasota County Boating Improvement Program, West Coast Inland Navigation District, and the Florida Fish and Wildlife Conservation Commission. Fuel and services for the surveys were kindly donated by Dolphin Aviation, Inc. The manuscript was improved by comments from ESR editor, Dr. Helene Marsh, and from 2 anonymous reviewers.

\section{LITERATURE CITED}

Ackerman BB (1995) Aerial surveys of manatees: a summary and progress report. In: O'Shea TJ, Ackerman BB, Percival HF (eds) Population biology of the Florida manatee. Information and Technology Report 1, National Biological Service, Washington, DC, p 13-33
Ackermann BB, Wright SD, Bonde RK, Odell DK Banowetz DJ (1995) Trends and patterns in mortality of manatees in Florida, 1974-1992. In: O'Shea TJ, Ackermann BB, Percival HF (eds) Population biology of the Florida manatee. Information and Technology Report 1, National Biological Service, Washington, DC, p 223-258

Burnham KP, Anderson DR, Laake JL (1980) Estimation of density from line transect sampling of biological populations. Wildl Monogr 72:3-202

Caughley GR (1977) Analysis of vertebrate populations. John Wiley \& Sons, London

Colmenero RLC, Zarate-Becerra E (1990) Distribution, status and conservation of West Indian manatee in Q. Roo, Mexico. Biol Conserv 52:27-35

Conroy MJ, Goldsberry JR, Hines JE, Stotts DB (1988) Evaluation of aerial transect surveys for wintering American black ducks. J Wildl Manag 52:694-703

Cook RD, Jacobson JO (1979) A design for estimating visibility bias in aerial surveys. Biometrics 35:735-742

$>$ Craig BA, Reynolds JE III (2004) Determination of manatee population trends along the Atlantic coast of Florida using a Bayesian approach with temperature-adjusted aerial survey data. Mar Mamm Sci 20:386-400

Craig BA, Newton MA, Garrott RA, Reynolds JE III, Wilcox JR (1997) Analysis of aerial survey data on Florida manatee using Markov Chain Monte Carlo. Biometrics 53:524-541

Crossett KM, Culliton TJ, Wiley PC, Goodspeed TR (2004) Population trends along the coastal United States, 1980-2008. US Department of Commerce, National Oceanic and Atmospheric Administration, National Ocean Service Special Projects Office, Silver Spring, MD

Dawes CJ, Phillips RC, Morrison G (2004) Seagrass communities of the gulf coast of Florida: status and ecology. Florida Fish and Wildlife Conservation Commission Fish and Wildlife Research Institute and the Tampa Bay Estuary Program, St. Petersburg, FL

Deutsch CJ, Reid JP, Bonde RK, Easton DE, Kochman HI, O'Shea TJ (2003) Seasonal movements, migratory behavior, and site fidelity of West Indian manatees along the Atlantic coast of the United States. Wildl Monogr 151:1-77

Dixon LK, Perry JS (2003) Analysis of changes in seagrass coverage, 1996-1999 and 1999-2001, for Anna Maria Sound, Sarasota, Roberts, Little Sarasota, and Blackburn Bays. Tech Rep No. 920, Mote Marine Laboratory, Sarasota, FL

Edwards HH, Pollock KH, Ackerman BB, Reynolds JE III, Powell JA (2007) Estimation of detection probability in manatee aerial surveys at a winter aggregation site. J Wildl Manag 71:2052-2060

FFWCC (Florida Fish and Wildlife Conservation Commission) (2002) Final biological status review of the Florida manatee (Trichechus manatus latirostris), December 2002. Florida Fish and Wildlife Conservation Commission, Florida Marine Research Institute, St. Petersburg, FL

FWRI (Florida Fish and Wildlife Research Institute) (2007) Manatee mortality Statistics 1974-2007. Available at: http://research.myfwc.com/manatees/

Gannon JG, Scolardi KM, Reynolds JE III, Koelsch JK, Kessenich TJ (2007) Habitat selection by groups of manatees with calves in the coastal waters of Sarasota County, Florida. Mar Mamm Sci 23:133-143

Garrott RA, Ackerman BB, Cary JR, Heisey DM, Reynolds JE III, Rose PM, Wilcox JR (1994) Trends in counts of Florida manatees at several winter aggregation sites. J Wildl Manag 58:642-654

Gorzelany J (2003) Sarasota County Manatee Protection Plan. Tech Rep No. 874, Mote Marine Laboratory, Sarasota, FL 
Hartman DS (1971) Behavior and ecology of the Florida manatee Trichechus manatus latirostris (Harlan), at Crystal River, Citrus County. PhD dissertation, Cornell University, Ithaca, NY

Hartman DS (1974) Distribution, status, and conservation of the manatee in the United States. NTIS Document PB81140725, National Technical Information Service, Springfield, VA

Irvine AB (1983) Manatee metabolism and its influence on distribution in Florida. Biol Conserv 25:315-334

Johansson JOR, Greening HS (1999) Seagrass restoration in Tampa Bay: a resource based approach to estuarine management. In: Bortone SA (ed) Seagrasses: monitoring, ecology, physiology, and management. CRC Press, Boca Raton, FL, p 279-293

Kinnaird MF (1985) Aerial census of manatees in northeastern Florida. Biol Conserv 32:59-79

Koelsch JK (1997) The seasonal occurrence and ecology of Florida manatees (Trichechus manatus latirostris) in coastal waters near Sarasota, FL. MS thesis, University of South Florida, Tampa, FL

Kurz RC, Tomasko DA, Burdick D, Ries TF, Patterson K, Finck $R$ (1999) Recent trends in seagrass distributions in southwest Florida coastal waters. In: Bortone SA (ed) Seagrasses: monitoring, ecology, physiology, and management. CRC Press, Boca Raton, FL, p 157-166

Laist DW, Reynolds JE III (2005) Florida manatees, warm-water refuges, and an uncertain future. Coast Manag 33:279-295

Langtimm CA, Beck CA, Edwards HH, Fick-Child KJ, Ackerman BB, Barton SL, Hartley WC (2004) Survival estimates for Florida manatees from the photo-identification of individuals. Mar Mamm Sci 20:438-463

Ledder DA (1986) Food habits of the West Indian manatee, Trichechus manatus latirostris, in south Florida. MS thesis, University of Miami, Coral Gables, FL

Lefebvre LW, Ackerman BB, Portier KM, Pollock KH (1995) Aerial survey as a technique for estimating trends in manatee population size - problems and prospects. In: O'Shea TJ, Ackerman BB, Percival HF (eds) Population biology of the Florida manatee. Information and Technology Report 1, National Biological Service, Washington, DC, p 63-74

Marine Mammal Commission (2005) Annual report to Congress 2004. Marine Mammal Commission, Bethesda, MD

Marsh H, Sinclair DF (1989) Correcting for visibility bias in strip transect aerial surveys of aquatic fauna. J Wildl Manag 53:1017-1024

Marsh H, Lawler IR, Kwan D, Delean S, Pollock K, Alldredge M (2004) Aerial surveys and the potential biological removal technique indicate that the Torres Strait dugong fishery is unsustainable. Anim Conserv 7:435-443

McCullagh P, Nelder JA (1989) Generalized linear models, 2nd edn. Chapman and Hall/CRC Press, Boca Raton, FL

Miller KE, Ackerman BB, Lefebvre LW, Clifton KB (1998) An evaluation of strip-transect aerial survey methods for monitoring manatee populations in Florida. Wildl Soc Bull 26:561-570

Morales-Vela B, Olivera-Gómez D (1994) Distribución espacial y estimación poblacional de los manatíes en la Bahía de Chetumal, Quintana Roo, Mexico. Rev Invest Cient 2 (UABC No. Esp. SOMEMMA) 2:27-34

- Morales-Vela B, Olivera-Gómez D, Reynolds JE III, Rathbun GB (2000) Distribution and habitat use by manatees (Trichechus manatus) in Belize and Chetumal Bay, Mexico. Biol Conserv 95:67-75

Morales-Vela B, Padilla-Saldivar J, Mignucci-Giannoni A (2003) Status of the manatee (Trichechus manatus) along the northern and western coasts of the Yucatan Peninsula, Mexico. Caribb J Sci 39:42-49

Mou Sou LL, Chen HD, Bonde RK, O'Shea TJ (1990) Distribution and status of manatees (Trichechus manatus) in Panama. Mar Mamm Sci 6:234-241

Nabor P, Patton GW (1989) Aerial studies of the West Indian manatee (Trichechus manatus) from Anna Maria Florida to northern Charlotte Harbor including the Myakka River: recommended habitat protection and manatee management strategies. Tech Rep No. 134, Mote Marine Laboratory, Sarasota, FL

O'Shea TJ, Ackerman BB (1995) Population biology of the Florida manatee: an overview. In: O'Shea TJ, Ackerman BB, Percival HF (eds) Population biology of the Florida manatee. Information and Technology Report 1, National Biological Service, Washington, DC, p 280-287

Packard JM (1985) Development of manatee aerial survey techniques. Manatee Population Research Report 7, Tech Rep 8-7, Florida Cooperative Fish and Wildlife Research Unit, University of Florida, Gainesville, FL

Packard JM, Summers RC, Barnes LB (1985) Variation of visibility bias during aerial surveys. J Wildl Manag 49: $347-351$

> Pollock KH, Kendall WL (1987) Visibility bias in aerial surveys: a review of estimation procedures. J Wildl Manag 51:502-510

Pollock KH, Marsh HD, Lawler IR, Alldredge MW (2006) Estimating animal abundance in heterogeneous environments: an application to aerial surveys for dugongs. J Wildl Manag 70:255-262

Powell JA, Rathbun GB (1984) Distribution and abundance of manatees along the northern coast of the Gulf of Mexico. Northeast Gulf Sci 7:1-28

Provancha JA, Hall CR (1991) Observations and associations between seagrass beds and manatees in east central Florida. Fla Sci 54:87-98

> Provancha JA, Provancha MJ (1988) Long-term trends in abundance and distribution of manatees (Trichechus manatus) in the northern Banana River, Brevard County, Florida. Mar Mamm Sci 4:323-338

Rathbun GB, Reid JP, Carowan G (1990) The distribution and movement patterns of manatees (Trichechus manatus) in northwestern peninsular Florida. Florida Marine Research Publ No. 48, St. Petersburg, FL

Reid JP, Rathbun GB, Wilcox JR (1991) Distribution patterns of individually identifiable West Indian manatees (Trichechus manatus) in Florida. Mar Mamm Sci 7: 180-190

Reynolds JE III (1999) Efforts to conserve the manatees. In: Twiss JR Jr, Reeves RR (eds) Conservation and management of marine mammals. Smithsonian Institute Press, Washington, DC, p 267-295

Reynolds JE III, Wilcox JR (1994) Observations of Florida manatees (Trichechus manatus latirostris) around selected power plants in winter. Mar Mamm Sci 10:163-177

> Runge MC, Langtimm CA, Kendall WL (2004) A stage-based model of manatee population dynamics. Mar Mamm Sci 20:361-385

Shane SH (1983) Abundance, distribution, and movements of manatees (Trichechus manatus) in Brevard County, Florida. Bull Mar Sci 33:1-9

Smith SK (2005) Florida population growth: past, present and future. Bureau of Economic \& Business Research, Gainesville, FL. Available at: www.bebr.ufl.edu

Tomasko DA, Dawes CJ, Hall MO (1996) The effects of anthropogenic nutrient enrichment on turtle grass (Tha- 
lassia testudinum) in Sarasota Bay, Florida. Estuaries 19: $448-456$

Tomasko DA, Corbett CA, Greening HS, Raulerson GE (2005) Spatial and temporal variation in seagrass coverage in southwest Florida: assessing the relative effects of anthropogenic nutrient load reductions and rainfall in four contiguous estuaries. Mar Pollut Bull 50: $797-805$

Editorial responsibility: Helene Marsh, Townsville, Queensland, Australia
USFWS (US Fish and Wildlife Service) (2001) Florida Manatee Recovery Plan, (Trichechus manatus latirostris), 3rd rvsn. US Fish and Wildlife Service, Atlanta, GA

Wright IE, Reynolds JE III, Ackerman BB, Ward LI, Weigle BL, Szelistowski WA (2002) Trends in manatee (Trichechus manatus latirostris) counts and habitat use in Tampa Bay, 1987-1994: implications for conservation. Mar Mamm Sci $18: 259-274$

Submitted: January 19, 2008; Accepted: August 21, 2009 Proofs received from author(s): October 14, 2009 